\title{
Phylogeographic study of brown trout from Serbia, based on mitochondrial DNA control region analysis
}

\author{
Saša MARIća ${ }^{\mathrm{a}}$, Simona SuŠniK ${ }^{\mathrm{b}}$, Predrag SIMONOVIĆa ${ }^{\mathrm{a}}$ Aleš SNOJ ${ }^{\mathrm{c} *}$ \\ a University of Belgrade, Faculty of Biology, Institute of Zoology, Studentski trg 16, \\ 11001 Belgrade, Serbia and Montenegro

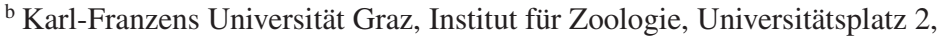 \\ A-8010 Graz, Austria \\ ${ }^{\mathrm{c}}$ University of Ljubljana, Biotechnical Faculty, Department of Animal Science, Groblje 3, \\ 1230 Domžale, Slovenia
}

(Received 8 September 2005; accepted 19 December 2005)

\begin{abstract}
In order to illuminate the phylogeography of brown trout (Salmo trutta) populations in the Balkan state of Serbia, the 561 bp 5'-end of mtDNA control region of 101 individuals originating from upland tributaries of the Danubian, Aegean and Adriatic drainages were sequenced and compared to corresponding brown trout sequences obtained in previous studies. Among 15 haplotypes found, 14 were considered native, representing the Danubian and Adriatic lineages of the brown trout, while one haplotype (ATcs1), found only in two individuals originating from two stocked rivers, corresponded to the Atlantic lineage and was considered introduced. Native haplotypes exhibited a strong geographic pattern of distribution: the Danubian haplotypes were strictly confined to the Danubian drainage, while the Adriatic haplotypes dominated in the Aegean and Adriatic drainages; most of the total molecular variance $(69 \%)$ was attributed to differences among the drainages. Phylogenetic reconstruction, supplemented with seven haplotypes newly described in this study, suggested a sister position of the Atlantic-Danubian and Adriatic-Mediterranean-marmoratus ("southern") phylogenetic group, and pointed to the existence of a distinct clade, detected within the "southern" group. The data obtained confirmed our expectation of the existence of high genetic diversity in Balkan trout populations, and we recommend more widespread surveys covering trout stocks from the region.
\end{abstract}

phylogeography / Salmo trutta / mitochondrial DNA / control region / Balkan Peninsula

\section{INTRODUCTION}

Brown trout (Salmo trutta) phylogeography has hitherto been largely investigated and much of the current understanding has come from molecular

\footnotetext{
*Corresponding author: ales.snoj@bfro.uni-lj.si
} 
studies based on nucleotide analysis of the mitochondrial DNA control region (mtDNA CR) $[6,8,11,13,14,17,30,31,36,37]$. For the last decade, it has been proposed [8] and subsequently agreed that five main evolutionary lineages of brown trout exist: the Danubian, Atlantic, Adriatic, Mediterranean and the form marmoratus. Recently, however, it has emerged that some regions may not have been sufficiently sampled and that there is still a deficiency of data from particular areas of the brown trout native range. For instance, recent comprehensive studies of brown trout from the Iberian Peninsula have revealed the existence of substantial polymorphism within the Atlantic clade $[30,36]$, so much that a new evolutionary lineage (Duero) has been proposed $[11,30]$. Moreover, the same studies have revealed that the distribution of Adriatic haplotypes far exceeds the range inferred by the name itself, and that the "Adriatic" clade spans the tributaries of the whole northern Mediterranean. In a recently released publication [31], a highly divergent haplotype that grouped within the Danubian clade was reported to be found in the upper part of the Tigris-Euphrates basin. These findings imply that the inclusion of under-explored brown trout stocks in phylogeographic studies is crucial for a fully comprehensive understanding of brown trout phylogeography and evolutionary history of the species. One such poorly explored area with importance to the post-glacial faunal evolution and colonisation of Europe is the Balkan Peninsula, now noted as a biodiversity hotspot [10,23]. This seems especially true if one bears in mind that the Balkan Peninsula (along with the Apennine and Iberian Peninsulas) was a refuge area during the Pleistocene glaciations $[18,19]$ and might therefore represent crossroads of different evolutionary patterns and processes. The ichthyofauna of the Balkan Peninsula is unusually complicated since each river basin, lake or mountain range has its own faunal peculiarities [5]. For Salmo taxa in particular, the area is believed to harbour the most phenotypic diversity present in brown trout populations. This is reflected in numerous taxa (e.g. S. farioides, S. labrax, S. macedonicus) that have been described for the region by early studies [20] (see also [22] for a review), and still the status of the majority of these is uncertain. It has already been pointed out that the absence of data from Balkan populations might be a main reason for the lack of clarification of brown trout phylogeny [22]. So far, only a limited number of studies investigating brown trout phylogeography in the Balkan Peninsula have been undertaken and these are mostly allozyme and mtDNA studies of Greek brown trout populations [2-4]. These studies, however, are not truly representative of Balkan populations, since they were limited to few short coastal streams belonging only to the Aegean and Adriatic-Ionian drainage. 
The territory of Serbia, one of the former Yugoslav republics, represents a conjunction of three main watersheds of Europe: the Danubian (Ibar and Morava rivers), Adriatic (Beli Drim River) and Aegean (Vardar and Struma rivers) drainages [16]. This area thus provides a convenient sampling ground likely to contain much phylogeographic information concentrated within a relatively small geographic range. During the Pleistocene, geotectonic events, including orographic mountain shifts and periodic volcanism [29] occurred in the area, causing several connections between water basins to be interrupted and reconnected, subsequently redistributing and isolating incipient trout populations. These specific historical conditions imply that locally isolated stocks do exist and strengthen the possibility that divergent lineages of brown trout inhabit this area.

The main goal of the present study was to closely examine the genetic diversity of brown trout in Serbia, using generally applied mtDNA CR as a marker of choice, in order to try to illuminate and resolve the phylogeography of brown trout populations in previously unstudied parts of its native range. In order to obtain a better insight into the relation between mtDNA haplotypes found in Serbia and the published brown trout data, corresponding CR sequences of several haplotypes already described for major mtDNA lineages were also included in the phylogenetic analysis.

\section{MATERIALS AND METHODS}

\subsection{Samples and DNA isolation}

A total of 101 brown trout from 35 locations across southern Serbia were collected by electrofishing and fly-fishing from 1997 until 2004. Sixty-one of these individuals came from 23 sample sites distributed across the tributaries in Serbia feeding the Danubian drainage, 20 from eight tributaries of the Vardar and Struma rivers (Dragovištica River) basins (Aegean drainage) and the remaining 20 from four upper stretches of the Beli Drim basin (Adriatic drainage) (Fig. 1). Most locations were assumed to contain only indigenous brown trout. The exceptions were the Gradac and Jerma Rivers (Danubian drainage), which are reported to be occasionally stocked with both domestic and non-indigenous brown trout (S. Đorđević and A. Panić, personal communication), and the Tripušnica River (Aegean drainage), which used to be virgin of trout till 1978, when brown trout originating from an unknown source in the Neretva basin (Adriatic drainage) were introduced (Archives of the Anglers' Association Trgovište). 


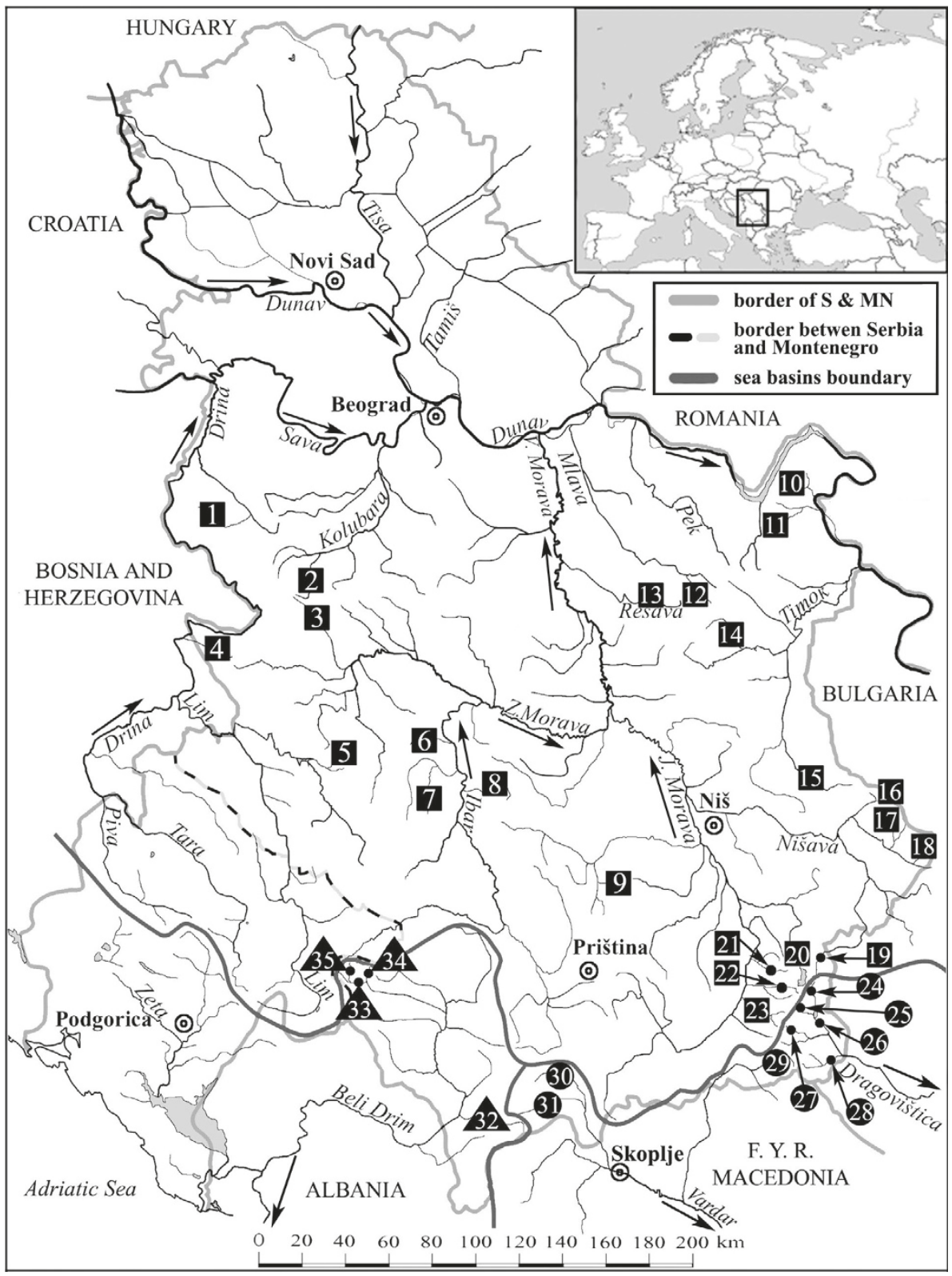

Figure 1. Sampling locations in Serbia. Names and locations of sampling sites are listed in Table I. The three main drainages are marked ( Danubian drainage, - Aegean drainage, $\boldsymbol{\Delta}$ Adriatic drainage). 
Phylogeography of brown trout in Serbia

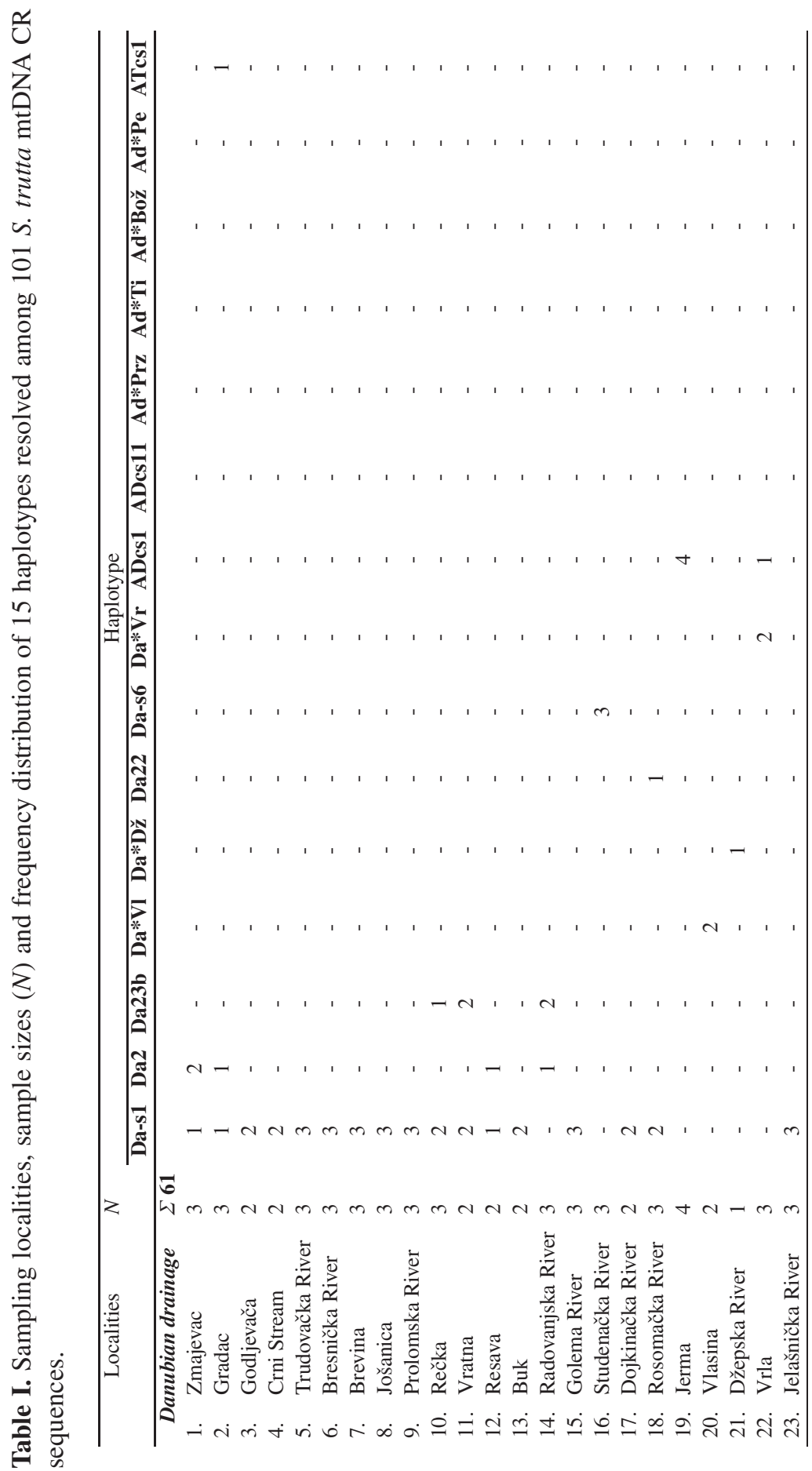




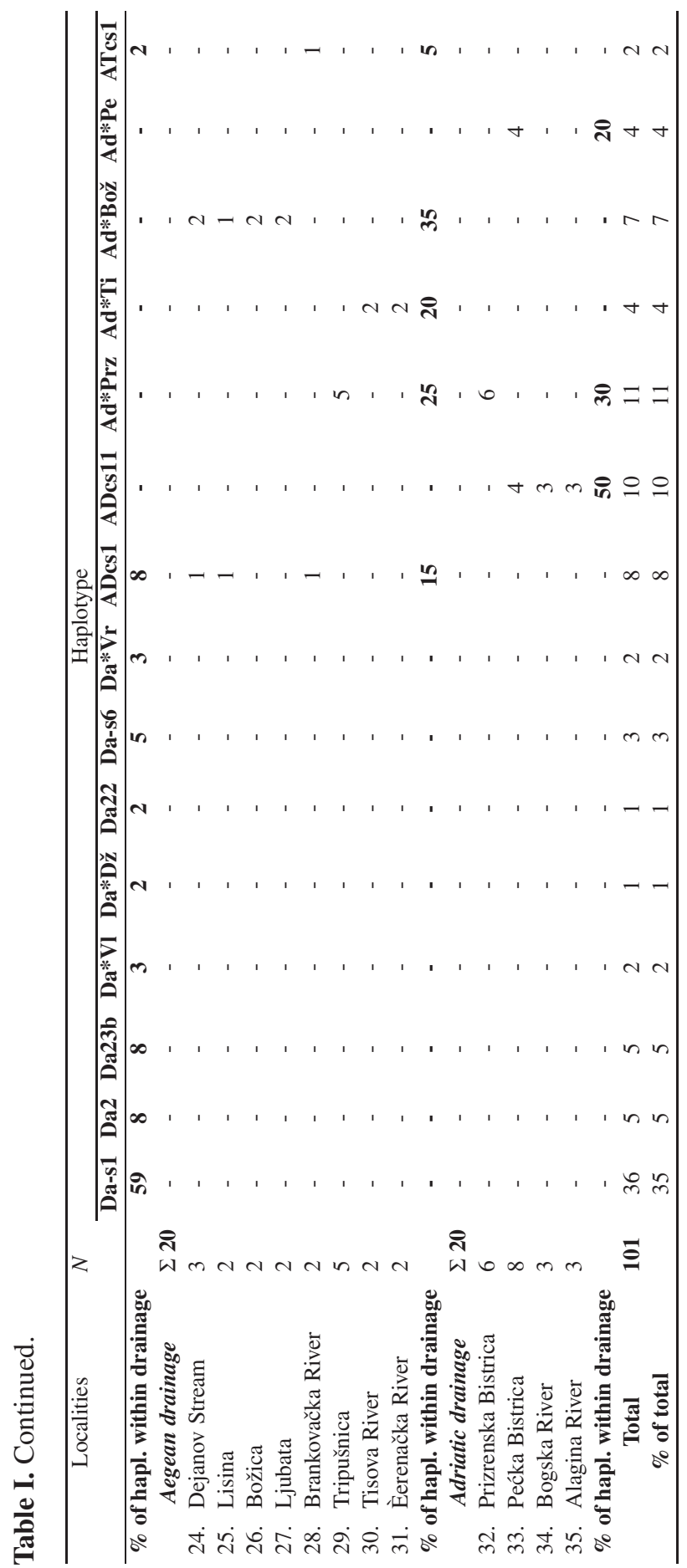


Total DNA was isolated from fin clips preserved in $96 \%$ ethanol using the Wizard Genomic DNA Purification Kit (Promega).

Mitochondrial DNA haplotypes reported in previous studies (At11a / AY185578, At10 / AY185577, from the Danubian drainage, Austria [14]; MAcs1 / AY836365 from the Adriatic drainage, Slovenia; MEcs1 / AY836350, MEcs7 / AY836356, from the Mediterranean drainage [12]; AdN / DQ297172 from the River Neretva, Adriatic drainage; Ma-s2 / DQ318130 from the Adriatic drainage, Slovenia) and used here for comparison, are represented in Table II. Sequences of newly observed haplotypes described herein, are available in GenBank under Accession Numbers DQ318123 - DQ318130.

\subsection{DNA amplification and sequencing}

The 5'-end of a $561 \mathrm{bp}$ segment of mtDNA CR was chosen for sequence analysis. PCR amplification of the entire CR ( $c a .1100 \mathrm{bp}$ ) was performed using primers 28RIBa [27] and HN20 [7]. The conditions for PCR were the following: initial denaturation $\left(95^{\circ} \mathrm{C}, 3 \mathrm{~min}\right)$ followed by 30 cycles of strand denaturation $\left(94^{\circ} \mathrm{C}, 45 \mathrm{~s}\right)$, primer annealing $\left(52{ }^{\circ} \mathrm{C}, 45 \mathrm{~s}\right)$ and DNA extension (72 $\left.{ }^{\circ} \mathrm{C}, 2 \mathrm{~min}\right)$. All PCR amplifications were performed in a programmable thermocycler GeneAmp ${ }^{\circledR}$ PCR System 9700 (AB Applied Biosystems). A total PCR volume of $30 \mu \mathrm{L}$ was used, containing $1 \mu \mathrm{M}$ of each primer, $0.2 \mu \mathrm{M}$ dNTP, $1.5 \mu \mathrm{M} \mathrm{MgCl}_{2}, 1 \times$ PCR buffer, $1 \mathrm{U}$ Taq polymerase (PE Applied Biosystems) and $100 \mathrm{ng}$ of genomic DNA. Amplified DNA fragments were run on a $1.5 \%$ gel and subsequently isolated from the gel using the QIAEX II gel Extraction Kit (QIAGEN).

All sequencing reactions were prepared using a BigDye Terminator Ready Reaction Mix (PE Applied Biosystems) according to the manufacturer's recommendations. The control region fragment between the tRNA ${ }^{\text {Pro }}$ gene and poly T-block was sequenced using primers 28RIBa [28]. Termination PCR reactions were performed in a programmable thermocycler under the following conditions: $10 \mathrm{~s}$ denaturation at $96{ }^{\circ} \mathrm{C}, 5 \mathrm{~s}$ annealing at $50{ }^{\circ} \mathrm{C}$ and 4 min extension at $60{ }^{\circ} \mathrm{C}$, repeated for 30 cycles. The amplified, fluorescently labelled and terminated DNA was salt-precipitated and analysed with an ABI PRISM 310 automated sequencer.

\subsection{Data analysis}

Sequences of the 5'-end of the mtDNA CR (561 bp) were aligned using the computer programme ClustalX [35]. Maximum parsimony (MP) and 
Neighbour-Joining (NJ) analyses were performed using the computer programme PAUP [32], with Salmo ohridanus (acc. no. AY260512) and S. salar (acc. no. U12143) included as outgroups. For MP, insertions or deletions (indels) were coded as a fifth character. A heuristic search (10 replicates) with TBR branch swapping was employed to find the shortest tree. For NJ, a Kimura 2-parameter model was chosen. Support for the nodes was obtained with 1000 bootstrap replicates for MP or NJ analysis.

Pairwise sequence divergences and net sequence divergences (between groups) were calculated with the Mega3 programme [24], applying the Kimura 2-parameter model [21].

Basic phylogenetic relationships between the CR sequences were also presented as a network using statistical parsimony criterion [34] in the TCS 1.3 programme [9].

The distribution of molecular variation was estimated by hierarchical nested analysis of molecular variance, Amova [15], using the software package Arlequin [26]. Three hierarchical levels were considered: (1) between basins, (2) among populations within basins and (3) within populations. Two models based on the main drainages (Danubian-Aegean-Adriatic and Aegean-Adriatic alone) were included in the analysis. The significance of variance components and $\Phi$-statistics were tested by multiple permutations $(1000 \times)$ of the original data set.

\section{RESULTS}

\subsection{Haplotype geographical distribution}

Fifteen haplotypes were resolved with sequence analysis of $561 \mathrm{bp}$ of mtDNA CR in 101 individuals analysed. The observed haplotypes were clearly segregated by major phylogenetic groups: the Danubian (Da), Mediterranean (Me)-Adriatic (Ad)-marmoratus (Ma) (hereafter referred to as "southern") or Atlantic (At) (Fig. 3).

The highest level of haplotype polymorphism was found in the Danubian drainage, reflected by the presence of eight different Da haplotypes, one Adand one At-haplotype (Tab. I). By far the most common haplotype was Da-s1, representing 59\% of all the haplotypes found in the Danubian drainage. The other Da haplotypes were considerably less frequent (from 2 to $8 \%$ ). Three of 
them (Da*Vl, Da*Dž and Da*Vr) were newly observed. The Da*Vr haplotype was most distinct and differed remarkably from the remaining Da haplotypes, apart from the Da*Dž haplotype, by mutation events at positions 228, 530, 542, 543 and 548 (Tab. II); the last four mutations were otherwise common to the majority of the haplotypes belonging to the other lineages (Ad, At, Ma and $\mathrm{Me})$, while three of them $(530,542$ and 548) were also characteristic of the Da*Dž haplotype (Tab. II).

In the Aegean-Adriatic drainage, seven haplotypes (six Adriatic and one Atlantic) were found. Four of them (i.e. Ad*Prz, Ad*Ti, Ad*Bož and Ad*Pe) have not been described before and were characterised by mutation events at sites 26, 126, 262, 387 and 543 (Tab. II). The Ad*Prz haplotype was found to be the most abundant (27\%) within the Aegean-Adriatic sampling locations (though only found in two locations; Tab. I), followed by ADcs11 (25\%) and $\mathrm{Ad}^{*} \mathrm{Bož}(17 \%)$, the rest only appearing at low frequencies (Tab. II).

The Atlantic haplotype was found in two individuals only, one coming from the Gradac River (Danubian drainage) and the other from the Brankovačka River (Aegean drainage).

Most haplotypes found in this study exhibited a strong geographic pattern of distribution: Da haplotypes were strictly confined to the Danubian drainage, whereas the "southern" ones dominated in the Aegean-Adriatic drainage with the exception of five individuals from the Danubian drainage (all individuals from the Jerma River and only one from the Vrla River) exhibiting the ADcs1 haplotype (Tab. I). Clear partitioning was also observed among the "southern" haplotypes, which were strictly associated with either the Aegean or Adriatic drainage except for the Ad*Prz haplotype, which was found in both drainages (in the rivers Prizrenska Bistrica in the Adriatic and Tripušnica in the Aegean drainage).

Under the model that considers the three main drainages (Danubian, Aegean and Adriatic) as the highest hierarchical level, brown trout genetic variability was partitioned significantly into all three estimated components (Tab. III). Most of the mtDNA molecular variance (69\%) was attributed to differences among the drainages, while a considerable amount of the variance $(23 \%)$ was also recorded within each drainage. Under the model that considers only the Aegean and Adriatic drainages, the molecular variance partition between the drainages was not statistically significant (Tab. III). When the sample site of the Tripušnica River was excluded from the analysis (see Material and Methods, and Discussion), the variance partition between the Aegean and Adriatic drainages was statistically significant $(p<0.001)$. 


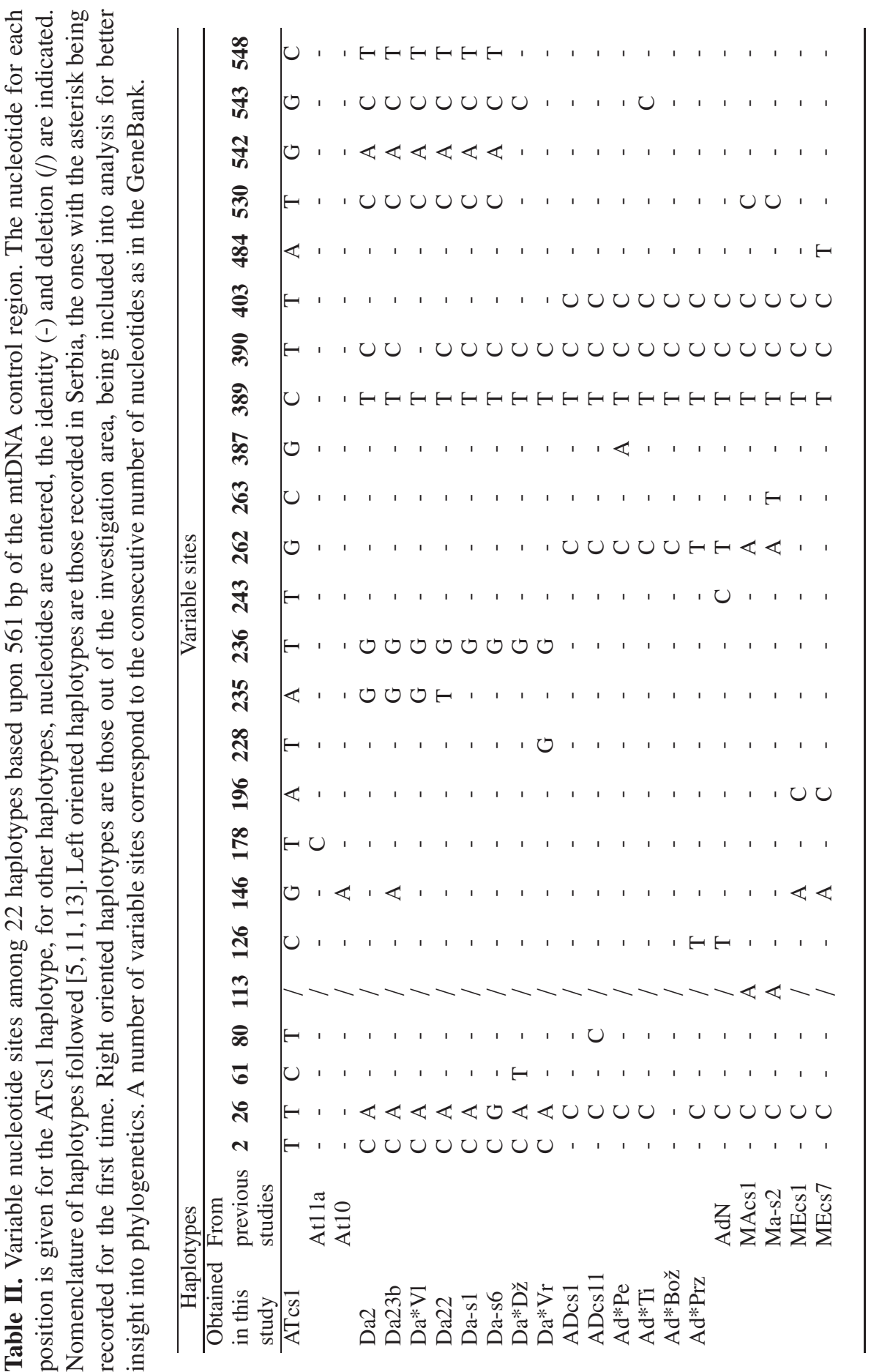


Phylogeography of brown trout in Serbia

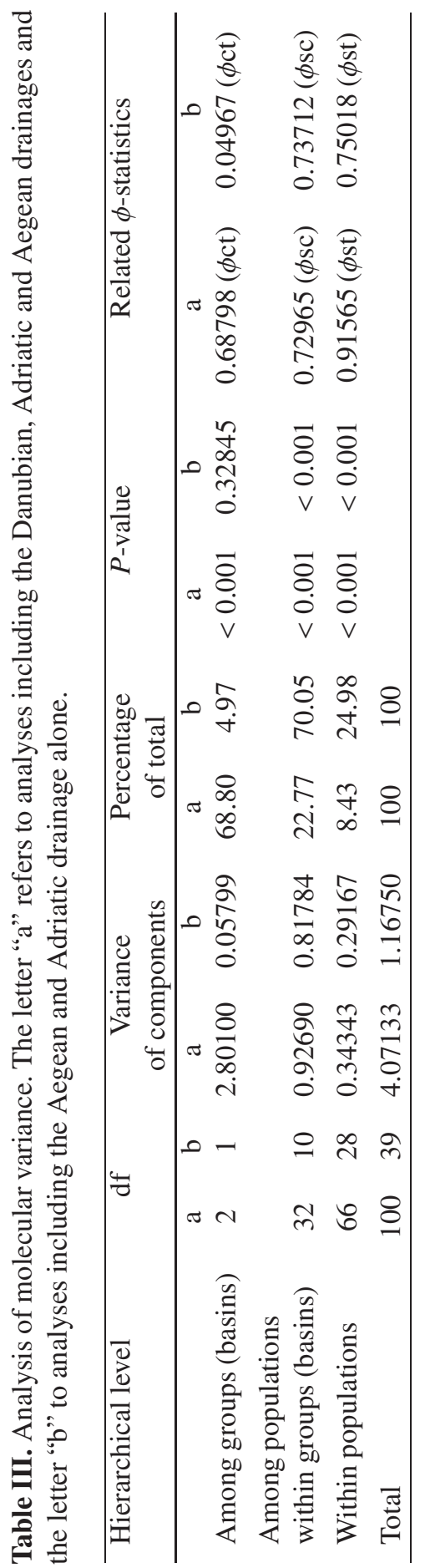




\subsection{Phylogenetic analysis}

The reconstruction of phylogeny by both parsimony and neighbour-joining methods revealed similar tree-topology of haplotypes belonging to the main phylogenetic brown trout lineages. The consensus tree rooted with two outgroups ( . salar and $S$. ohridanus) (Fig. 2) revealed highly supported clear delimitation of two main clades (Da and At plus the "southern" clade). Topology within both, the Danubian and "southern" clades was, however, less supported. Particularly, the basal position of the Ad*Bož haplotype within the "southern" clade had no bootstrap support for MP and only 54\% bootstrap support for NJ. Nevertheless, two already known subdivisions (Mediterranean and marmoratus) plus an additional one, composed of $\mathrm{Ad} * \mathrm{Prz}$ and $\mathrm{AdN}$ haplotypes, were identified within the "southern" clade, while the Adriatic clade (in the narrow sense; see Introduction) was not resolved.

As inferred from the nucleotide survey, the members of the Me, Ma and Ad*Prz-AdN clusters were characterised by similar number of intra-clade synapomorphies, (positions 113, 262 and 530 for Ma, 146 and 196 for Me, 126 and 262 for Ad*Prz-AdN; Tab. II), which suggests similar deep divergence of these clades.

In comparison to the "southern" clade, the Danubian clade exhibited much more profound genetic divergence $(0.6 \%$ of "within group average genetic distance"), three times the genetic divergence seen within "southern" clades. Regarding the branching pattern within the Danubian clade, the $\mathrm{Da} * \mathrm{Vr}$ (and $\mathrm{Da}^{*} \mathrm{Dz}$ ) haplotype, which took the basal position in the clade was noteworthy.

Genealogical relationships among the haplotypes, seen in the minimum spanning haplotype network (Fig. 3), revealed the central position of the Adcs1 haplotype within the group of "southern" haplotypes; the remaining Ad haplotypes were equally related and differed from the central one by a single mutation event, with the exception of the Ad*Prz haplotype, which differed by two mutations. Within the Danubian clade, the central position was taken by the Da-s1 haplotype, while the most distinct haplotypes were Da*Vr and Da*Dž, separated from the central one by five and four mutations, respectively. Within the whole network, the $\mathrm{Da} * \mathrm{Vr}$ haplotype was more or less equally separated from the Danubian ( $\geq$ five mutations), Atlantic ( $\geq$ five mutations) or "southern" clade ( $\geq$ six mutations). This observation was highlighted through the genetic distances (Tab. IV), which ranged from 1.05 to $1.23 \%$ between $\mathrm{Da} * \mathrm{Vr}$ versus the "southern" and At haplotypes, and from 0.88 to $1.23 \%$ between $\mathrm{Da}^{*} \mathrm{Vr}$ and the remaining Da haplotypes, with the exception of the closely related $\mathrm{Da} * \mathrm{D} z ̌$ haplotype, which was separated from $\mathrm{Da} * \mathrm{Vr}$ by a genetic distance 
of $0.5 \%$. The average genetic distance among the other Da haplotypes was $0.26 \%$ and $0.3 \%$ among haplotypes of the "southern" clade.

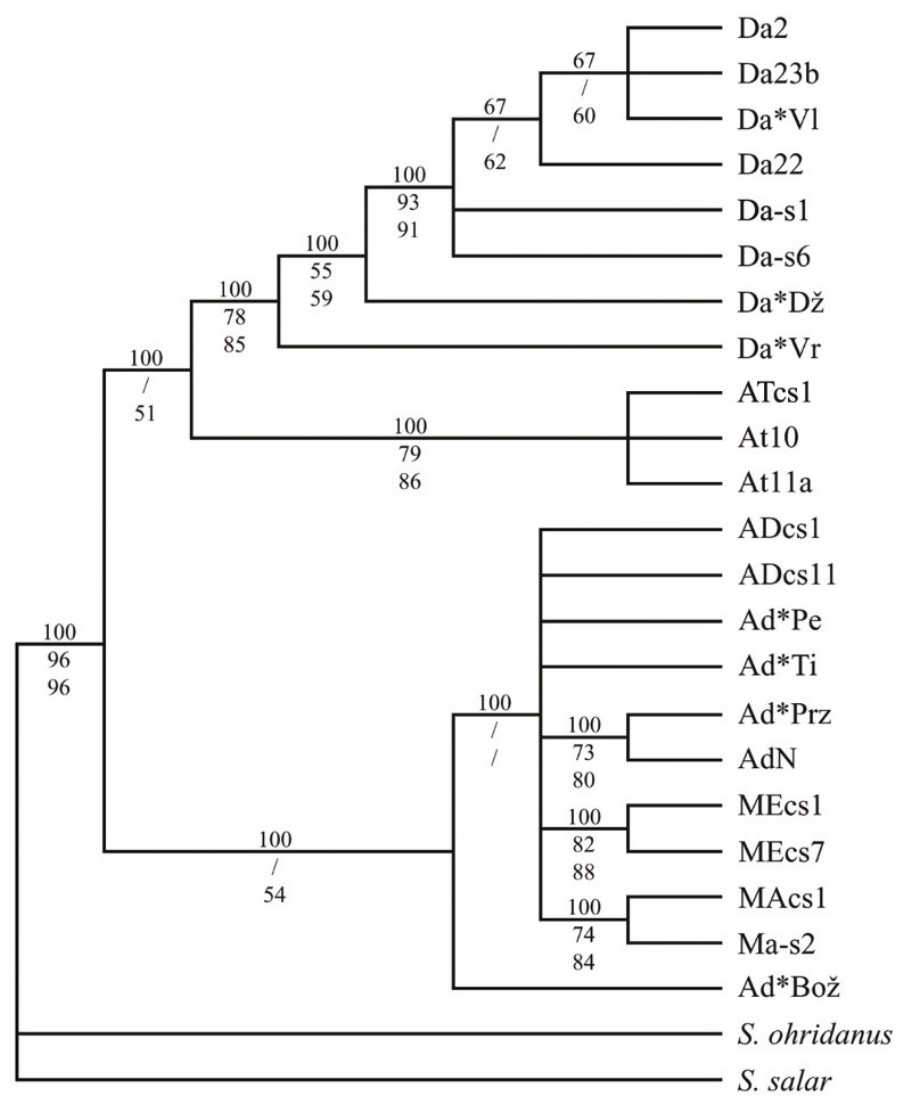

Figure 2. Inferred phylogeny of Serbian mitochondrial DNA (mtDNA) haplotypes in relation to already published haplotypes of all five phylogenetic lineages within Salmo trutta. The tree was constructed applying Maximum Parsimony majority rule $50 \%$ consensus algorithm implemented in PAUP 4 software package, using 5'-end sequence of the mtDNA CR. Tree was rooted with $S$. ohridanus and $S$. salar sequences of mtDNA CR. Node support is shown by percent bootstraps (only those $\geq 50 \%$ are indicated) for MP majority rule 50\% consensus (above the line), for MP consensus (1000 replicates; first bellow the line) and NJ (1000 replicates; second below the line). Abbreviations stand for: Me-Mediterranean, Ad-Adriatic, Da-Danubian, Ma-marmoratus and At-Atlantic lineage within Salmo trutta species complex, as first presented in Bernatchez et al. [8]. 
S. Marić et al.

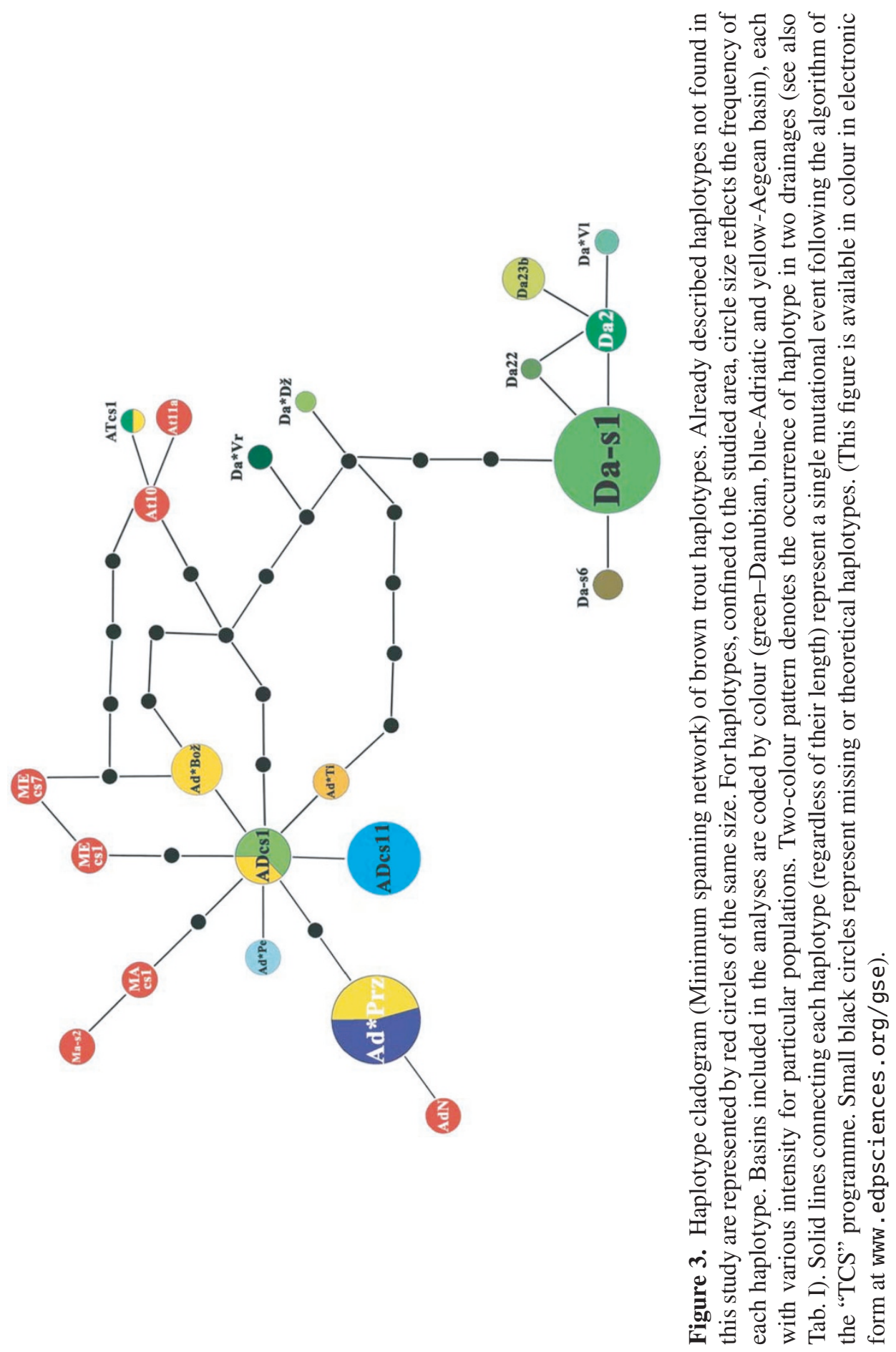


Phylogeography of brown trout in Serbia

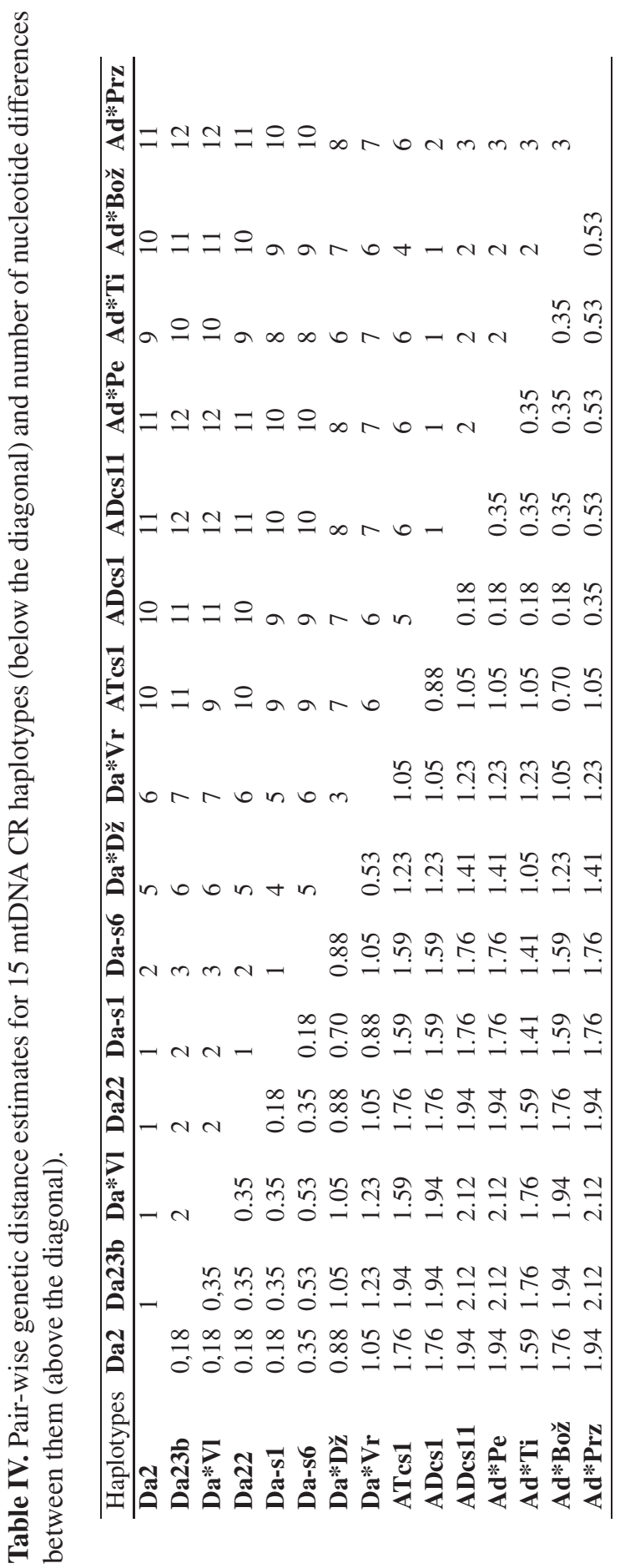




\section{DISCUSSION}

The present study reveals the existence of three main phylogeographic lineages of brown trout in the territory of Serbia: the Danubian, "southern" (containing Ad and its related haplotypes) and Atlantic. Brown trout of the Danubian and "southern" mtDNA lineages were expected to exist within the corresponding drainages and this was found to be the case. However, the presence of the Adriatic haplotype in the Danubian drainage and the Atlantic one in Danubian and Aegean drainages was not expected. The latter finding is controversial for the streams of the upper Danube region, since it still has not been determined whether the At lineage is native to the Danubian drainage as suggested by some authors $[8,37]$, or not. Regarding the situation in Serbia, both, the Danubian and Aegean drainages are known to be stocked with hatcheryreared strains. Since all At individuals bore the ATcs1 haplotype, which is prevalent in commercially available strains, it is most reasonable to assume that it has been anthropogenically introduced into the Serbian rivers. The presence of an Adriatic haplotype found in the Danubian drainage (in the Jerma and Vrla rivers) is likely a consequence of direct fish transfer from one drainage into another: for example, trout-farms situated on upper reaches of the Aegean drainage in western Bulgaria have been largely used for stocking of the Jerma River (A. Panić, personal communication). This may be the main reason why only the Ad haplotype was found there. Water pumping from the Struma River (Aegean drainage) to the Vlasina River reservoir [25] that supplies hydropower plants located on the Vrla River, may have been another efficient means of fish transfer between the drainages.

Despite having one haplotype in common, clear genetic partitioning between the Adriatic and Aegean drainages was found. It should be recalled that the presence of the shared haplotype Ad*Prz found in the Aegean drainage is a consequence of brown trout transfer undertaken during the 1970s, when brown trout from the Neretva basin (Adriatic drainage, Bosnia and Herzegovina) were introduced into the Tripušnica River (Archives of the Anglers'Association of Trgovište). The natural range of the Ad*Prz haplotype, therefore, likely comprises not only the Prizrenska Bistrica River, as found in this study, but also the Neretva basin. It is worth noting at this point that the Ad*Prz haplotype is highly related to the AdN haplotype (Tab. II, Fig. 2); both haplotypes formed a clade that was statistically supported with the same level of probability as the already established clades (e.g. Me and Ma) and all three clades were equally distant from the central ADcs1 haplotype (Fig. 3). The AdN haplotype has also been found in native brown trout of the Neretva basin. It is therefore evident that the Ad*Prz and AdN haplotypes are associated with the same river 
systems of the southwestern Balkans and that they show similar patterns of geographic distribution. Most interestingly, the joint distribution of the haplotypes corresponds well to the distribution of Salmo farioides, proposed by Karaman $[13,20]$, which was erected in 1938 to classify allegedly distinct brown trout of the southwestern Balkans (see also [13, 20, 22, 33]). All these lines of evidence lead us to the intriguing speculation that genetically distinct lineages of brown trout may have evolved in the southwestern Balkans. Although the current information may not be sufficient to draw any firm conclusions, we nevertheless suggest that some consideration should be given to this idea since it may have the potential to resolve an interesting aspect of brown trout evolutionary history in the Balkan Peninsula.

The topology resolution between the main evolutionary lineages (i.e., Danubian, Atlantic and "southern") of $S$. trutta is despite several already performed phylogenetic studies (e.g., $[6,12,28])$ still unclear and not uniformly interpreted. We expected that the inclusion of the additional outgroup $S$. ohridanus would improve it, however, the clustering of the At clade with the Da one was weak (Fig. 2) and therefore a branching order for the main clades remained unresolved. Nevertheless, several ancestral character states found in the most basal haplotypes within the Danubian clade (Sect. 3.1, Tab. II) suggested that the Danubian populations might be the oldest fragmented lineage of the $S$. trutta complex. The ancestral position of the Da lineage has been recently implied through nucleotide analysis of complete CR of mtDNA [12] and corroborated by a study based on the transferrin gene [1]. Some extremely divergent Danubian haplotypes, such as the Da*Vr and Da*Dž haplotypes representing the intermediate position within the entire haplotype network (Fig. 3), or as previously described haplotypes Da26 found in the upper Tigris [31], and Da24 found in the northern Danubian Drainage in Austria [14], additionally suggest the long existence of the Da clade in S. trutta evolution.

\subsection{Conclusion}

Our study shows that indigenous brown trout still exist in Serbia, at least in the upper reaches of main watercourses. This information is of particular importance for management strategies, especially in terms of maintaining autochthonous genetic diversity of brown trout, both in Serbia and neighbouring countries.

High genetic diversity revealed through several newly described polymorphisms found within different brown trout lineages and through extremely deep divergence within the Danubian populations, was characteristic of the 
populations of trout studied throughout the sampled area in southern Serbia. Since this area represents only a minor part of the whole Balkan Peninsula, genetic polymorphism of the brown trout within the region as a whole may be considered even higher. This level of genetic polymorphism along with the suspected existence of an evolutionary distinct lineage within the Adriatic drainage, suggests that an extended analysis of Balkan brown trout, especially stocks from the countries adjacent to Serbia (i.e., Montenegro, Albania, Macedonia, Bulgaria and Bosnia-Herzegovina), need to be performed in the future.

\section{ACKNOWLEDGEMENTS}

We thank S. Weiss for his assistance with data analysis and A. Razpet for technical assistance in the lab. We are also especially grateful to Iain Wilson for linguistic improvements of the manuscript. This work was supported by the Slovenian Ministry of Education, Science and Sport (Grant No. BI-CS/04-05003) and Ministry of Science and Environment Protection of the Republic of Serbia (Grant No. ON 143040).

\section{REFERENCES}

[1] Antunes A., Templeton A.R., Guyomard R., Alexandrino P., The role of nuclear genes and intraspecific evolutionary inference: genealogy of transferrin gene in the brown trout, Mol. Biol. Evol. 19 (2002) 1272-1287.

[2] Apostolidis A., Karakousis Y., Triantaphyllidis C., Genetic divergence and phylogenetic relationships among Salmo trutta L. (brown trout) populations from Greece and other European countries, Heredity 76 (1996) 551-560.

[3] Apostolidis A., Karakousis Y., Triantaphyllidis C., Genetic differentiation and phylogenetic relationships among Greek Salmo trutta L. (brown trout) populations as revealed by RFLP analysis of PCR amplified mitochondrial DNA segments, Heredity 77 (1996) 608-618.

[4] Apostolidis A.P., Triantaphyllidis C., Kouvatsi A., Economidis P.S., Mitochondrial DNA sequence variation and phylogeography among Salmo trutta L. (Greek brown trout) populations, Mol. Ecol. 6 (1997) 531-542.

[5] Bănărescu P., Distribution pattern of the aquatic fauna of the Balkan peninsula, in: Griffiths H.I., Kryštufek B. (Eds.), Balkan Biodiversity, Pattern and process in the European hotspot, Kluwer Academic Publishers, Dordrecht-Boston-London, 2004, pp. 203-217.

[6] Bernatchez L., The evolutionary history of brown trout (Salmo trutta L.) inferred from phylogenetic, nested clade, and mismatch analyses of mitochondrial DNA variation, Evolution 55 (2001) 351-379. 
[7] Bernatchez L., Danzmann R.G., Congruence in control-region sequence and restriction-site variation in mitochondrial DNA of brook charr (Salvelinus fontinalis Mitchill), Mol. Biol. Evol. 10 (1993) 1002-1014.

[8] Bernatchez L., Guyomard R., Bonhomme F., DNA sequence variation of the mitochondrial control region among geographically and morphologically remote European brown trout Salmo trutta populations, Mol. Ecol. 1 (1992) 161-173.

[9] Clement M., Posada D., Crandall K., TCS: A computer program to estimate gene genealogies, Mol. Ecol. 9 (2000) 1657-1660.

[10] Conservation International (2004) http://www.conservation.org/xp/CIWEB/home

[11] Cortey M., García-Marín J.L., Evidence for phylogeographically informative sequence variation in the mitochondrial control region of Atlantic brown trout, J. Fish Biol. 60 (2002) 1058-1063.

[12] Cortey M., Pla C., García-Marín J.L., Historical biogeography of Mediterranean trout, Mol. Phylogenet. Evol. 33 (2004) 831-844.

[13] Delling B., Species diversity and phylogeny of Salmo with emphasis on southern trouts (Teleostei, Salmonidae), Department of Zoology, Stockholm University, 2003.

[14] Duftner N., Weiss S., Medgyesy N., Sturmbauer C., Enhanced phylogeographic information about Austrian brown trout populations derived from complete mitochondrial control region sequences, J. Fish Biol. 62 (2003) 427-435.

[15] Excoffier L., Smouse P.E., Quattro J.M., Analysis of molecular variance inferred from metric distances among DNA haplotypes: application to human mitochondrial DNA restriction data, Genetics 131 (1992) 479-491.

[16] Gavrilović Lj., Dukić D., Reke Srbije, Zavod za udžbenike i nastavna sredstva, Beograd, 2002.

[17] Giuffra E., Bernatchez L., Guyomard R., Mitochondrial control region and protein coding genes sequence variation among phenotypic forms of brown trout Salmo trutta from Northern Italy, Mol. Ecol. 3 (1994) 161-172.

[18] Hewitt G.M., Some genetic consequences of ice ages, and their role in divergence and speciation, Biol. J. Linn. Soc. 58 (1996) 274-276.

[19] Hewitt G.M., Post-glacial re-colonization of European biota, Biol. J. Linn. Soc. 68 (1999) 87-112.

[20] Karaman S., Beitrag zur Kenntnis der Süsswasserfische Jugoslaviens, Glasnik Skopskog naučnog društva 18 (1937) 131-139.

[21] Kimura M., A simple model for estimating evolutionary rates of base substitutions through comparative studies of nucleotide sequences, J. Mol. Evol. 16 (1980) 11-120.

[22] Kottelat M., European freshwater fishes, An heuristic checklist of the freshwater fishes of Europe (exclusive of former USSR), with an introduction for nonsystematists and comments on nomenclature and conservation, Biol. Brat. 52 (suppl. 5) (1997) 1-271.

[23] Kryštufek B., Reed J.M., Pattern and Process in Balkan Biodiversity - an Overview, in: Griffiths H.I., Kryštufek B., Reed J.M. (Eds.), Balkan Biodiversity, Pattern and Process in the European Hotspot, Kluwer Academic Publishers, Dordrecht, 2004, pp. 203-217. 
[24] Kumar S., Tamura K., Nei M., MEGA3: Integrated software for Molecular Evolutionary Genetics Analysis and sequence alignment, Brief. Bioinform. 5 (2004) 150-164.

[25] Ocokoljić M., Visinsko zoniraje voda u slivu Velike Morave i neki aspekti njihove zaštite, Posebna izdanja Srpskog geografskog društva, Beograd, Sveska 64, 1987.

[26] Schneider S., Roessli D., Excoffier L., Arlequin: A software for population genetics data analysis, Ver. 2.000. Genetics and Biometry Lab, Dept. of Anthropology, University of Geneva, 2000.

[27] Snoj A., Jug T., Melkič E., Sušnik S., Pohar J., Dovč P., Budihna N., Mitochondrial and microsatellite DNA analysis of marble trout in Slovenia, J. Fish Biol. (Quaderni ETP) 29 (2000) 5-11.

[28] Snoj A., Melkič E., Sušnik S., Muhamedagić S., Dovč P., DNA phylogeny supports revised classification of Salmothymus obtusirostris, Biol. J. Linn. Soc. 77 (2002) 399-411.

[29] Stevanović M.P., Istorijska geologija, Rudarsko Geološki fakultet Univerziteta u Beogradu, Beograd, 1982.

[30] Suárez J., Bautista J.M., Almodóvar A., Machordom A., Evolution of mitochondrial control region in Palaeartic brown trout (Salmo trutta) populations: the biogeographical role of the Iberian Peninsula, Heredity 87 (2001) 198-206.

[31] Sušnik S., Schöffmann J., Weiss S., Genetic verification of native brown trout from the Persian Gulf (Catak Cay River, Tigris basin), J. Fish Biol. 67 (2005) 879-884.

[32] Swofford D.L., PAUP*, b-VERSION 4.0. Sunderland, MA: Sinauer, 2000.

[33] Šorić V., Salmonids in the Ohrid - Drim - Skadar system, Acta Soc. Zool. Bohemoslov 54 (1990) 305-319.

[34] Templeton A.R., Crandall K.A., Sing C.F., A cladistic analysis of phenotypic association with haplotypes inferred from restriction endonucleases mapping and DNA sequence data. III. Cladogram estimation, Genetics 132 (1992) 619-633.

[35] Thompson J.D., Higgins D.G., Gibson T.J., Clustal W: improving the sensitivity of progressive multiple sequence alignment through sequence weighting, position-specific gap penalties and weight matrix choice, Nucl. Acids Res. 22 (1994) 4637-4680.

[36] Weiss S., Antunes A., Schlötterer C., Alexandrino P., Mitochondrial haplotype diversity among Portuguese brown trout Salmo trutta L. populations: relevance to the post-Pleistocene recolonization of northern Europe, Mol. Ecol. 9 (2000) 691-698.

[37] Weiss S., Schlötterer C., Waidbacher H., Jungwirth M., Haplotype (mtDNA) diversity of brown trout Salmo trutta in tributaries of the Austrian Danube: massive introgresion of Atlantic basin fish - by man or nature?, Mol. Ecol. 10 (2001) 1241-1246. 